\title{
The effect of the biostimulator Goteo on the rooting of ninebark stem cuttings
}

\author{
Andrzej Pacholczak*, Karolina Nowakowska, Natalia Mika, Monika Borkowska \\ Department of Ornamental Plants \\ Faculty of Horticulture, Biotechnology and Landscape Architecture \\ Warsaw University of Life Sciences \\ Nowoursynowska 166, 02-787 Warsaw, Poland
}

\begin{abstract}
As a consequence of restrictions on the use of preparations containing synthetic auxins in nursery production, there is a necessity to replace them with more environmentally friendly biopreparations efficiently stimulating plant growth. The aim of the presented experiment was to compare the effects of the synthetic auxin indole3-butyric acid (IBA) and the biostimulator Goteo on the rooting of ninebark stem cuttings (Physocarpus opulifolius 'Dart's Gold' and 'Red Baron') and to get some insight into the latter's mechanisms of action in plants. Applications of the biostimulator Goteo produced comparable or slightly weaker effects compared to the treatments with IBA. Goteo stimulated elongation in new growth of cuttings when applied in watering or two-fold spraying methods. Application of the biostimulator resulted in increased levels of chlorophyll, soluble sugars and indole derivatives, while the contents of free amino acids and polyphenolic acids decreased. The above results indicate that, if necessary, Goteo may replace the synthetic auxin IBA in the propagation of ninebark in the future.
\end{abstract}

Key words: biopreparations, carbohydrates, chlorophyll, cuttings, organic compounds, rhizogenesis

\section{INTRODUCTION}

Biostimulators are most often grouped according to their chemical composition or their effects exerted on plants. The main purpose of their application is to limit stress effects on plants. They also improve the quality of plant material and hasten processes of plant growth and development. Biostimulators control physiological processes; for example, intensifying water uptake and nutrient transport as well as stimulating photosynthesis (Dobrzański et al. 2008, Pruszyński 2008). They contain active substances of natural origin or microorganisms and when used directly on plants or in the rhizosphere they stimulate processes occurring in plants on each level of biological organization. Investigations on biostimulators such as Kelpak, Goëmar, AlgaminoPlant, Pentakeep- $\mathrm{V}$ and Route and their modes of action have been carried out for years to make their application feasible in the future in place of synthetic preparations, whose use may be banned due to new EU regulations (Dobrzański et al. 2008, Basak 2013, du Jardin 2015). Knowledge on the above mentioned preparations is poorer than that concerning the biostimulator Asahi SL (Gawrońska et al. 2008, Przybysz et al. 2010), so studies on them still need to be carried out. The mechanisms of the biostimulators' action on physiological and biochemical processes in plants often remain unknown, mostly because of the great

\footnotetext{
*Corresponding author.

Tel.: +48 2259322 68; fax: +48 2259322 68;

e-mail: andrzej_pacholczak@sggw.pl (A. Pacholczak).
} 
diversity of raw materials used for their production (du Jardin 2015, Ertani et al. 2015). According to Khan et al. (2009), seaweed extracts - the common ingredients of biopreparations - not only affect the growth and development of root systems but also control the contents of organic compounds in plants. Gawrońska et al. (2008), Wróbel and Woźniak (2008) and Borowski (2009) showed that photosynthetic pigment levels increase due to the use of biostimulators. Chlorophyll content and photosynthetic rate affect carbohydrate levels in plants, thus the plant energy status. Carbohydrate accumulation, especially that of sugars in their simplest forms, may be decisive for rhizogenesis, especially in its initial phase (Costa et al. 2007). The results of studies on the use biostimulators Grevit 200 SL and Biochikol 020 PC for the propagation of barberry and ninebark (Jacygrad and Pacholczak 2010, Pacholczak et al. 2010) and AlgaminoPlant and Route for ninebark and white dogwood (Pacholczak et al. 2012, 2013, Pacholczak and Pietkiewicz 2014) seem promising and offer a hope for an alternative to synthetic auxins in the propagation of ornamental shrubs.

The biostimulator Goteo (Arysta LifeScience Polska) is a liquid preparation stimulating the formation of a rhizogenic layer. It contains: GA142 - biologically active filtrate from the seaweed Ascophyllum nodosum, phosphorus - 13\% when calculated as $\mathrm{P}_{2} \mathrm{O}_{5}$, and $5 \%$ potassium as $\mathrm{K}_{2} \mathrm{O}$. The recommended dosage for hastening root system regeneration is a series of 3-4 treatments with $0.2 \%$ solution, every two weeks (Matysiak et al. 2010, Gajc-Wolska et al. 2012).

The ninebark cultivars used in the experiment, Physocarpus opulifolius Maxim. 'Dart's Gold' and 'Red Baron', are shrubs with decorative leaves, very resistant to air pollution and low temperatures, which makes them valuable for urban green areas, especially when planted on roadsides. They are also often grown in public parks and home gardens (Dirr 2009). As a demand for ninebark is increasing, all of the methods used to improve propagation efficiency are important for nurserymen.

As our earlier trials with biostimulators gave promising results in rhizogenesis, we have undertaken this experiment, whose aim was to evaluate the effects of the biostimulator Goteo on the rooting of stem cuttings in two ninebark cultivars (Physocarpus opulifolius 'Dart's Gold' and 'Red Baron'), and to get some insight into the mechanism of its action in plants. In order to evaluate the potential of Goteo to replace synthetic auxins in plant propagation in the future, its effects were compared to those exerted by IBA, commonly applied in nurseries both as commercial powders or as IBA water solutions.

\section{MATERIAL AND METHODS}

The experiment was carried out between 26 June and 20 August 2015, in the commercial nursery M.M. Kryt in Wola Prażmowska on two ninebark cultivars (Physocarpus opulifolius Maxim. 'Dart's Gold' and 'Red Baron'). Semi-lignified, two-nodal cuttings were made from stems harvested from four-year-old stock shrubs grown outdoors. The cuttings were placed in Styrofoam flats filled with a mixture of peat and coarse sand, v/v 2:1 of $\mathrm{pH}$ 4.9-5.1, and placed under a plastic tunnel. Cuttings were inserted at a depth of $2 \mathrm{~cm}$. Rooting took place in plastic tunnels, equipped with automatic watering and mist systems. The conditions during rooting were: temperature of $25-28^{\circ} \mathrm{C}$ and relative humidity of $90-100 \%$. During the first two weeks, the cuttings were protected against the sun with an opaque foil and a shading cloth. Each week, the cuttings were prophylactically sprayed with fungicides Topsin $0.1 \%$ or Teldor $0.1 \%$. There were seven treatments, each in three replications, each containing 20 cuttings, which were treated on the first day. The control cuttings were sprayed only with water. The commercial rooting powder Rhizopon AA containing $1 \%$ auxin indole-3-butyric acid (IBA) was used as a reference treatment allowing us to assess the efficiency of the other treatments. The powder was applied to the damp stems' bases. IBA and Goteo solutions were applied on cuttings with a pressure hand sprayer, and attention was paid to cover all of the plant surface. The cuttings were completely covered with the solutions until drop off. Goteo was also applied on the growing medium - the cuttings were watered with its solution. The treatments with the biostimulator were performed once (treatment 4 and 6) or twice

Table 1. A list of treatments in the experiment

\begin{tabular}{ll}
\hline Treatment & Method of cutting treatment \\
\hline 1 & Control '0' 1 spraying with distilled water \\
2 & Rhizopon AA (1\% IBA) powder \\
3 & $1 \times$ spraying with IBA $200 \mathrm{mg} \mathrm{l}^{-1}$ \\
4 & $1 \times$ spraying with Goteo $0.2 \%$ \\
5 & $2 \times$ spraying with Goteo $0.2 \%$ \\
6 & $1 \times$ watering with Goteo $0.2 \%$ \\
7 & $2 \times$ watering with Goteo $0.2 \%$ \\
\hline
\end{tabular}


Table 2. Evaluation scale of root development

\begin{tabular}{lc}
\hline Characteristics of the degree of rooting & Score \\
\hline Cutting without visible roots & 1 \\
A few (1-3) short roots & 2 \\
$4-5$ roots, some of them branched, no root ball formed & 3 \\
Medium sized root system composed of 6-10 branched roots forming a root ball & 4 \\
Well developed, branched root system forming a root ball (over 10 roots) & 5 \\
\hline
\end{tabular}

(treatment 5 and 7), at the beginning of the experiment and one week later (Tab. 1).

Percentages of rooted cuttings and the degree of rooting were determined eight weeks after the start of the experiment. The degree of rooting was evaluated on a five-point scale rating the development of the root ball (Tab. 2). The percentage of rooted cuttings was also calculated - only the cuttings with a root system within the scale range of 2-5 were regarded as rooted and counted. The scores for the degree of rooting represent the means of three independent observations by trained personnel.

\section{Biochemical analyses}

20 cuttings per treatment were sampled at the beginning and the end of the experiment for biochemical analyses. They were finely chopped, mixed, and $0.5 \mathrm{~g}$ samples were used for the measurements. Triplicate extracts were prepared for each analysis and three measurements were done for each extract, producing nine readings for each data point.

The total chlorophyll content was analysed according to Lichtenthaler and Wellburn (1983). Total soluble sugars were determined according to Dubois et al. (1956), while free amino acids were measured using Rosen's method (Rosen 1957). The content of indole derivatives was measured using the Gordon-Weber colorimetric method (Gordon and Weber 1951) with the Salkowski reagent (Ehmann 1977) and expressed as IAA equivalents. Polyphenolic acids were measured using the colorimetric method with Arnow's reagent according to Polish Norm PN-91/R-87019 (Farmakopea Polska 2002).

\section{Statistical analysis}

Arcsine transformation was performed for all experimental data taken in the experiment before subjecting them to statistical analysis (Snedecor and Cochran 1967). To compare the means, percentages of rooted cuttings were transformed according to Bliss. All data - percentages of rooted cuttings and results of biochemical analyses - were subjected to one-factorial ANOVA followed by the NewmanKeuls test at $p=0.05$ (Wójcik and Laudański 1989).

\section{RESULTS AND DISCUSSION}

\section{Rooting of cuttings}

Since the role of auxins in rhizogenesis was recognized, they have been used to stimulate this process in cuttings, especially in difficult-to-root woody plants. Due to restrictions in the use of synthetic auxins imposed by the EU, investigations have been developed on preparations obtained from seaweeds, citrus fruits or crustacea in hope that they may become an alternative for synthetic growth regulators (Shevchenko 2008, Szabó and Hrotkó 2009, Poşta and Hernea 2011, Kowalska et al. 2012).

All of the treatments significantly affected the degree and percentage of rooting in both ninebark cultivars (Tabs 3 and 4). The lowest rooting degree was found in the control untreated cuttings and in cuttings watered twice with $0.2 \%$ Goteo solution. A considerable improvement of the root ball development was observed after foliar Goteo application: a single treatment in 'Dart's Gold' or two sprayings in 'Red Baron'. These results were comparable to those obtained due to IBA application, both as Rhizopon AA or the water solution (IBA $200 \mathrm{mg} \mathrm{l}^{-1}$ ). A nearly twofold increase in the percentage of rooted cuttings in 'Dart's Gold' resulted from spraying either with the Goteo solution or IBA or the application of the powder Rhizopon AA. In 'Red Baron', the best results were obtained after treatments with IBA; however, comparable or slightly inferior results were observed in cuttings sprayed with the $0.2 \%$ water solution of Goteo. Pirlak (2000) tested a range of IBA concentrations while rooting cuttings of white dogwood and found $60 \mathrm{mg} \mathrm{l}^{-1}$ to be the most suitable for foliar application. In this experiment, IBA in a concentration of $200 \mathrm{mg} \mathrm{l}^{-1}$ used for foliar application gave results comparable to those obtained with the commercial rooting powder Rhizopon AA. Earlier trials on three ninebark 
Table 3. The degree of rooting in cuttings of Physocarpus opulifolius 'Dart's Gold' and 'Red Baron'

\begin{tabular}{lccccccc}
\hline Cultivar & Control & Rh. AA & $\begin{array}{c}\text { Spray } \\
200 \mathrm{mg} \mathrm{l}^{-1}\end{array}$ & $\begin{array}{c}\text { Spray } \\
\text { Goteo } 0.2 \% \\
(1 \text { time })\end{array}$ & $\begin{array}{c}\text { Spray } \\
\text { Goteo 0.2\% } \\
(2 \text { times })\end{array}$ & $\begin{array}{c}\text { Watering } \\
\text { Goteo 0.2\% } \\
(1 \text { time })\end{array}$ & $\begin{array}{c}\text { Watering } \\
\text { Goteo 0.2\% } \\
(2 \text { times })\end{array}$ \\
\hline Dart's Gold & $1.7 \mathrm{a}^{*}$ & $3.4 \mathrm{c}$ & $3.0 \mathrm{c}$ & $2.8 \mathrm{bc}$ & $2.4 \mathrm{~b}$ & $2.5 \mathrm{~b}$ & $2.0 \mathrm{ab}$ \\
Red Baron & $2.6 \mathrm{a}$ & $3.8 \mathrm{c}$ & $3.7 \mathrm{c}$ & $2.8 \mathrm{~b}$ & $3.9 \mathrm{c}$ & $2.4 \mathrm{a}$ & $2.5 \mathrm{a}$ \\
\hline
\end{tabular}

*Values marked with the same letter do not differ significantly at $p=0.05$

Table 4. The percentage of rooting in cuttings of Physocarpus opulifolius 'Dart's Gold' and 'Red Baron'

\begin{tabular}{|c|c|c|c|c|c|c|c|}
\hline Cultivar & Control & Rh. AA & $\begin{array}{c}\text { Spray } \\
200 \mathrm{mg} \mathrm{l}^{-1} \\
\text { IBA }\end{array}$ & $\begin{array}{c}\text { Spray } \\
\text { Goteo } 0.2 \% \\
(1 \text { time }) \\
\end{array}$ & $\begin{array}{c}\text { Spray } \\
\text { Goteo } 0.2 \% \\
(2 \text { times })\end{array}$ & $\begin{array}{c}\text { Watering } \\
\text { Goteo } 0.2 \% \\
(1 \text { time }) \\
\end{array}$ & $\begin{array}{c}\text { Watering } \\
\text { Goteo } 0.2 \% \\
(2 \text { times })\end{array}$ \\
\hline Dart's Gold & $40.5 \mathrm{a}^{*}$ & $86.7 \mathrm{~d}$ & $76.7 \mathrm{~cd}$ & $83.3 \mathrm{~d}$ & $85.0 \mathrm{~d}$ & $63.3 \mathrm{~b}$ & $61.7 \mathrm{~b}$ \\
\hline Red Baron & $43.3 \mathrm{a}$ & $90.0 \mathrm{~d}$ & $90.0 \mathrm{~d}$ & $85.3 \mathrm{~cd}$ & $75.5 \mathrm{c}$ & $58.3 \mathrm{~b}$ & $53.3 \mathrm{~b}$ \\
\hline
\end{tabular}

*Explanations: see Table 3

cultivars showed that the treatments with the water solution of IBA (Jacygrad and Pacholczak 2010) or biostimulators (Pacholczak et al. 2013) were the most efficient for rooting.

Zaman et al. (2015) studied the effects of seaweed extracts on the biomass of shoots in Lolium perenne. Kumar and Sahoo (2011) showed that preparations containing algae extracts increased shoot height in their investigations on Triticum aestivum. Enhanced new shoot elongation was observed for ninebark cuttings in the present study (Tab. 5). In 'Dart's Gold', the new shoots were almost twice as long as the control ones, while in 'Red Baron' the increase in their length was $30 \%$ and $44 \%$ after a single or two-fold treatment with Goteo, respectively. Mugnai et al. (2008) reported a similar positive effect of algae extracts on shoot elongation and further plant growth in another woody plant, Vitis vinifera. Neither the application of the commercial powder nor a single spraying with IBA or Goteo stimulated new growth elongation; on the contrary, their growth was weakened in 'Dart's Gold'.

\section{Biochemical parameters}

In general, all of the treatments significantly affected the contents of organic compounds and indole derivatives in ninebark cuttings (Tab. 6). The contents of total chlorophyll increased relative to the controls in both cultivars due to single or two-fold watering with $0.2 \%$ Goteo solution by $25 \%$ and $30 \%$, respectively.

An elevated chlorophyll level (nearly 20\%) was also found in 'Red Baron' cuttings sprayed with Goteo or IBA solution. Khan et al. (2009) reported that the extract from Ascophylum nodosum in low concentrations increased the level of assimilation pigments in tomato leaves. Such an increase in chlorophyll content resulting from biostimulator application was also observed in dogwood cuttings (Pacholczak et al. 2012), wheat (Vician and Kováčik 2013) or tomato (Mikiciuk and Dobromilska 2014). According to Kranner et al. (2003), an increase in chlorophyll content may be a defence response to stresses what would be in line with the general opinion that biopreparations increase plant tolerance to unfavourable growing conditions.

All of the treatments increased total soluble and reducing sugar contents as compared to the controls. The highest total soluble sugar content was determined in 'Red Baron' cuttings sprayed twice with Goteo or watered twice with the biopreparation solution, where it was $42 \%$ higher than in the untreated cuttings. In 'Dart's Gold', two-fold foliar application or watering with Goteo resulted in over a $20 \%$ increase in total soluble carbohydrates. The reducing sugar content in 'Dart's Gold'

Table 5. New growth in cuttings of Physocarpus opulifolius 'Dart's Gold' and 'Red Baron'

\begin{tabular}{lccccccc}
\hline Cultivar & Control & Rh. AA & $\begin{array}{c}\text { Spray } \\
\text { IBA } \mathrm{mg} \mathrm{l}^{-1}\end{array}$ & $\begin{array}{c}\text { Spray } \\
\text { Goteo } 0.2 \% \\
(1 \text { time })\end{array}$ & $\begin{array}{c}\text { Spray } \\
\text { Goteo } 0.2 \% \\
(2 \text { times })\end{array}$ & $\begin{array}{c}\text { Watering } \\
\text { Goteo 0.2\% } \\
(1 \text { time })\end{array}$ & $\begin{array}{c}\text { Watering } \\
\text { Goteo } 0.2 \% \\
(2 \text { times })\end{array}$ \\
\hline Dart's Gold & $1.6 \mathrm{~b}^{*}$ & $0.5 \mathrm{a}$ & $0.5 \mathrm{a}$ & $1.8 \mathrm{~b}$ & $2.1 \mathrm{c}$ & $3.2 \mathrm{~d}$ & $3.3 \mathrm{~d}$ \\
\hline Red Baron & $3.0 \mathrm{bc}$ & $2.6 \mathrm{~b}$ & $1.5 \mathrm{~b}$ & $2.7 \mathrm{~b}$ & $3.8 \mathrm{~cd}$ & $3.9 \mathrm{~d}$ & $4.3 \mathrm{~d}$ \\
\hline
\end{tabular}

*Explanations: see Table 3 
Table 6. The total chlorophyll, total soluble sugars, reducing sugars ( $\mathrm{mg} \mathrm{g}^{-1} \mathrm{D} . \mathrm{W}$.), free amino acids ( $\mu$ mol g $\mathrm{g}^{-1}$ leucine D.W.), indole derivatives ( $\mu$ g IAA $\mathrm{g}^{-1} \mathrm{D}$.W.) and polyphenolic acids ( $\mathrm{mg} \mathrm{g}^{-1} \mathrm{D}$.W.) contents in cuttings of Physocarpus opulifolius 'Dart's Gold' and 'Red Baron'

\begin{tabular}{|c|c|c|c|c|c|c|c|c|}
\hline Content & Cultivar & Control & Rh. AA & $\begin{array}{c}\text { Spray } \\
200 \mathrm{mg} \cdot \mathrm{l}^{-1} \\
\text { IBA }\end{array}$ & $\begin{array}{c}\text { Spray } \\
\text { Goteo } 0.2 \% \\
(1 \text { time })\end{array}$ & $\begin{array}{c}\text { Spray } \\
\text { Goteo } 0.2 \% \\
(2 \text { times })\end{array}$ & $\begin{array}{c}\text { Watering } \\
\text { Goteo } 0.2 \% \\
(1 \text { time })\end{array}$ & $\begin{array}{c}\text { Watering } \\
\text { Goteo } 0.2 \% \\
(2 \text { times })\end{array}$ \\
\hline \multirow{2}{*}{ Chlorophyll } & Dart's Gold & $3.5 \mathrm{a}^{*}$ & $3.7 \mathrm{a}$ & $3.5 \mathrm{a}$ & $3.6 \mathrm{a}$ & $3.6 \mathrm{a}$ & $4.3 \mathrm{~b}$ & $4.5 \mathrm{~b}$ \\
\hline & Red Baron & $5.8 \mathrm{a}$ & $5.8 \mathrm{a}$ & $7.0 \mathrm{~b}$ & $6.9 \mathrm{~b}$ & $6.9 \mathrm{~b}$ & $7.3 \mathrm{~b}$ & $7.8 \mathrm{c}$ \\
\hline \multirow{2}{*}{ Total soluble sugars } & Dart's Gold & $9.4 \mathrm{a}$ & $10.9 \mathrm{bc}$ & $10.2 \mathrm{ab}$ & $11.1 \mathrm{~cd}$ & $11.4 \mathrm{~cd}$ & $10.7 \mathrm{bc}$ & $11.8 \mathrm{~d}$ \\
\hline & Red Baron & $9.7 \mathrm{a}$ & $12.1 \mathrm{c}$ & $11.0 \mathrm{~b}$ & $11.6 \mathrm{bc}$ & $13.8 \mathrm{~d}$ & $11.7 \mathrm{bc}$ & $12.5 \mathrm{~cd}$ \\
\hline \multirow{2}{*}{ Reducing sugars } & Dart's Gold & $5.3 \mathrm{a}$ & $5.7 \mathrm{~b}$ & $5.4 \mathrm{a}$ & $5.7 \mathrm{~b}$ & $5.8 \mathrm{~b}$ & $5.9 \mathrm{~b}$ & $6.0 \mathrm{~b}$ \\
\hline & Red Baron & $5.0 \mathrm{a}$ & $6.3 \mathrm{~b}$ & $6.6 \mathrm{~b}$ & $6.5 \mathrm{~b}$ & $7.2 \mathrm{c}$ & $6.5 \mathrm{~b}$ & $6.5 \mathrm{~b}$ \\
\hline \multirow{2}{*}{ Free amino acids } & Dart's Gold & $243.3 \mathrm{~b}$ & $175.1 \mathrm{a}$ & $157.8 \mathrm{a}$ & $167.9 \mathrm{a}$ & $159.2 \mathrm{a}$ & $157.5 \mathrm{a}$ & $159.9 \mathrm{a}$ \\
\hline & Red Baron & $377.6 \mathrm{c}$ & $241.9 \mathrm{ab}$ & $228.6 \mathrm{a}$ & $222.9 \mathrm{a}$ & $229.8 \mathrm{a}$ & $263.8 \mathrm{~b}$ & $262.8 \mathrm{~b}$ \\
\hline \multirow{2}{*}{ Indole derivatives } & Dart's Gold & $1.545 \mathrm{a}$ & $1.882 \mathrm{~b}$ & $1.854 \mathrm{~b}$ & $1.708 \mathrm{ab}$ & $2.194 \mathrm{c}$ & $1.714 \mathrm{ab}$ & $1.726 \mathrm{ab}$ \\
\hline & Red Baron & $1.536 \mathrm{a}$ & $2.487 \mathrm{~b}$ & $2.549 \mathrm{~b}$ & $2.395 \mathrm{~b}$ & $2.946 \mathrm{c}$ & $2.630 \mathrm{~b}$ & $2.518 \mathrm{~b}$ \\
\hline \multirow{2}{*}{ Polyphenolic acids } & Dart's Gold & $8.5 \mathrm{c}$ & $8.0 \mathrm{c}$ & $7.4 \mathrm{bc}$ & $6.4 \mathrm{ab}$ & $6.7 \mathrm{~b}$ & $6.1 \mathrm{a}$ & $6.7 \mathrm{~b}$ \\
\hline & Red Baron & $23.9 \mathrm{c}$ & $23.4 \mathrm{c}$ & $23.6 \mathrm{c}$ & $20.2 \mathrm{~b}$ & $20.7 \mathrm{~b}$ & $18.9 \mathrm{~b}$ & $14.7 \mathrm{a}$ \\
\hline
\end{tabular}

*Explanations: see Table 3

increased by $10 \%$ after the application of Goteo or Rhizopon AA. Rathore et al. (2009) reported an increase in carbohydrates in Glycine max treated with a preparation based on alga Kappaphycus alvarezii while Sivasankari et al. (2006) observed similar effects of seaweed extracts in Vigna sinensis. Agulló-Antón and Sánchez-Bravo (2011) also observed an over two-fold increase in total soluble sugars in Dianthus caryophyllus cuttings treated with auxins.

An increase in free amino acids positively affects the vitality of plant cells and their proper functioning (Lessufleur et al. 2007). Their content fell by $30 \%$ on average in ninebark cuttings due to the biopreparation applications. Different results were obtained in white dogwood, where free amino acids increased after the use of another biopreparation, AlgaminoPlant (Pacholczak et al. 2012).

Auxins, and especially IAA, are very unstable and their concentration in plants depends on the species (cultivar), the site of the cutting's harvest, stock plant age, light, water, etc. (Jankiewicz 1997). Ford et al. (2001) observed a decrease in IAA content in lilac cuttings treated with IBA, from $125 \mu \mathrm{g} \mathrm{g}^{-1}$ D.W. at the beginning of the rooting period to $12.5 \mu \mathrm{g} \mathrm{g}^{-1}$ D.W. at its end. A similar tendency was reported by Osterc et al. (2009) in 'Autumnalis' cherry stems. In this study, the contents of endogenous and indole derivatives increased after treatments with IBA and Goteo, especially after two-fold spraying with the biostimulator, where the increases relative to the control were
45\% and two-fold in 'Dart's Gold' and 'Red Baron', respectively. This is in line with reports by Scagel and Linderman (2001), who in cuttings treated with growth stimulators observed a 50\%, 40\% and $30 \%$ increase in endogenous auxin in Douglas fir, lodgepole pine and Engelman's spruce, respectively.

As compared to the control, the contents of polyphenolic acids decreased due to treatments with the biostimulator - by $25 \%$ and $20 \%$ in 'Dart's Gold' and 'Red Baron', respectively. Elhaak et al. (2015) also observed decreases in their content in cuttings of rosemary treated with $0.01 \%$ IBA. Similarly, Rosłon et al. (2011) reported a decrease in polyphenolic acids in basil plants watered with the biostimulators Aminoplant and Goëmar Goteo.

The results presented here show that biostimulators may enhance rooting and may be helpful for other researchers willing to evaluate the effects of growth regulators on plant growth and development and physiological processes occurring during growth. Further investigations are needed in order to find the best concentrations of biostimulator and application methods to stimulate rooting of a given species or cultivar.

\section{CONCLUSIONS}

1. The applications of biostimulator Goteo produced comparable or slightly weaker effects to treatments with IBA. 
2. Goteo stimulated elongation in new growth of cuttings when applied in watering or two-fold spraying methods.

3. The application of Goteo resulted in increased levels of chlorophyll, soluble sugars and indole derivatives while the contents of free amino acids and polyphenolic acids decreased.

\section{FUNDING}

This research was supported by the State Committee for Scientific Research as a part of the project: The intensification of propagation of ornamental shrubs by using biostimulants (NN 310725140).

\section{AUTHOR CONTRIBUTIONS}

A.P. contributed to the entire experimental process, biochemical and data analysis, interpretation, literature search and writing. K.N., N.M. and M.B were involved in the determination of biochemical compounds.

\section{CONFLICT OF INTEREST}

Authors declare no conflict of interest.

\section{REFERENCES}

Agulló-Antón M.A., SÁnchez-Bravo J., 2011. Auxins or sugars: What makes the difference in the adventitious rooting of stored carnation cuttings? J. Plant Growth Regul. 30: 100-113.

BASAK A., 2013. Biostymulator czy już nawóz? [Biostimulator is already fertilizer?] MPS Sad 5: 8385.

Borowski E., 2009. Response to chilling in cucumber (Cucumis sativus L.) plants treated with triacontanol and Asahi SL. Acta Agrobot. 62: 165-172.

Costa J.M., Heuvelink E., Pol P.A., Put H.M.C., 2007. Anatomy and morphology of rooting in leafy rose stem cuttings and starch dynamics following severance. Acta Hort. 751: 495-502.

Dirr M.A., 2009. Manual of Woody Landscape Plants. Stipes Publishing L.L.C., Champaign, France.

Dobrzański A., Anyszka Z., Elkner K., 2008. Reakcja marchwi na ekstrakty pochodzenia naturalnego $\mathrm{z}$ alg z rodzaju Sargassum - AlgaminoPlant i z leonardytu

- HumiPlant [Carrot response to natural extracts from Sargassum algae - AlgaminoPlant and from leonardit - HumiPlant]. J. Res. Appl. Agric. Engng. 53: 53-58.

Dubois M., Gilles K.A., Hamilton J.K., Rebers P.A., Sмітн F., 1956. Colorimetric method for determination of sugars and related substances. Anal. Chem. 28: 350-356.
DU JARDIN P., 2015. Plant biostimulants: Definition, concept, main categories and regulation. Sci. Hort. 196: 3-14.

Ehmann A., 1977. The van Urk-Salkowski reagent a sensitive and specific chromogenic reagent for silica gel thin-layer chromatographic detection and identification of indole derivatives. J. Chromatogr. 132: 267-276.

ElhaAk M.A., Matter M.Z., Zayed M.A., Gad D.A., 2015. Propagation principles in using indole-3butrytic acid for rooting rosemary stem cuttings. J. Horticulture 2: 2-13.

Ertani A., Sambo P., Nicoletto C., Santagata S., Schiavon M., Nardi S., 2015. The use of organic biostimulants in hot pepper plants to help low input sustainable agriculture. Chem. Biol. Technol. Agric. 2: 11 .

Farmakopea Polska 2002. [Polish Pharmacopoeia]. PTF, Warszawa, Poland: 895-897.

Ford Y.Y., Bonham E.C., Cameron R.W.F., Blake P.S., Judd H.L., Harrison-Murray R.S., 2001. Adventitious rooting examining the role of auxin in easy- and a difficult-to-root plant. Plant Growth Regul. 36(2): 149-159.

Gajc-Wolska J., Kowalczyk K., Nowecka M., Mazur K., Metera A., 2012. Effect of organic-mineral fertilizers on the yield and quality of endive (Cichorium endivia L.). Acta Sci. Pol., Hortorum Cultus 11(3): 189-200.

Gawrońska H., Przybysz A., Szalacha E., SŁowiński A., 2008. Physiological and molecular mode of action of Asahi SL biostimulator under optimal and stress conditions. In: Biostimulators in Modern Agriculture. General Aspects. H. Gawrońska (ed.), Wieś Jutra, Warsaw, Poland: 54-76.

Gordon S.A, Weber R.P., 1951. Colorimetric estimation of indoleacetic acid. Plant Physiol. 26: 192-195.

JACYGRAD E., PACHOLCZAK A., 2010. Effect of biopreparations Amino Total and Biochikol 020 PC on rhizogenesis in stem cuttings of Physocarpus opulifolius 'Dart's Gold' and 'Diabolo'. Ann. Warsaw Univ. Life Sci. - SGGW, Horticult. Landsc. Architect. 31: 19-28.

JANKIEWICZ L.S., 1997. Regulatory wzrostu i rozwoju roślin [Regulators of Plant Growth and Development]. PWN, Warszawa, Poland: 108-123.

Khan W., Rayirath U.P., Subramanian S., Jithesh M.N., Rayorath P., Hodges D.M., et al. 2009. Seaweed extracts as biostimulants of plant growth and development. J. Plant Growth Regul. 28: 386-399.

Kowalska J., Golka W., Ptaszyński S., 2012. Uwarunkowania legislacyjne dotyczące środków wspomagających uprawę roślin i wymagania techniczne ich aplikacji [Legislation aspects of using the strengtheners in plant cultivation and technical requirements for their application]. PIR 2(76): 4754. 
Kranner I., Zorn M., Turk B., Wornik S., Beckett R.P., BAtı̌̌ F., 2003. Biochemical traits of lichens differing in relative desiccation tolerance. New Phytol. 160(1): 167-176.

Kumar G., Sahoo D., 2011. Effect of seaweed liquid extract on growth an yield of Triticum aestivum var. Pusa Gold. J. Appl. Physiol. 23: 251-255.

Lessufleur F., Paynel F., Bataillé M.P., Le DeunfF E., Cliquet J.B., 2007. Root amino acid exudation: measurement of high efflux rates of glycine and serine from six different plant species. Plant Soil 294: 235-246.

Lichtenthaler H.K., Wellburn A.R., 1983. Determinations of total carotenoids and chlorophylls $\mathrm{a}$ and $\mathrm{b}$ leaf extracts in different solvents. Biochem. Soc. Trans. 603: 591-592.

Matysiak K., Kaczmarek S., Kierzek R., Kardasz P., 2010. Effect of seaweeds extracts and humic and fulvic acids on the germination and early growth of winter oilseed rape (Brassica napus L.). J. Res. Appl. Agric. Engng. 55: 28-32.

Mikiciuk M., Dobromilska R., 2014. Assessment of yield and physiological indices of small-sized tomato cv. 'Bianka $\mathrm{F}_{1}$ ' under the influence of biostimulators of marine algae origin. Acta Sci. Pol., Hortorum Cultus 13(1): 31-41.

Mugnai S., Azzarello E., Pandolfi C., Salamagne S., Briand X., Mancuso S., 2008. Enhancement of ammonium and potassium root influxes by the application of marine bioactive substances positively affects Vitis vinifera plant growth. J. Appl. Phycol. 20: 177-182.

Osterc G., Štefančıč M., Štampar F., 2009. Juvenile stock plant material enhances root development through higher endogenous auxin level. Acta Physiol. Plant. 31: 899-903.

Pacholczak A., Szydeo W., Pijus J., 2010. Effect of preparation Asahi SL on rhizogenesis in stem cuttings of Physocarpus opulifolius 'Dart's Gold' and 'Diabolo'. Ann. Warsaw Univ. Life Sci. SGGW, Horticult. Landsc. Architect. 31: 11-18.

Pacholczak A., Szydeo W., Jacygrad E., Federowicz M., 2012. Effect of auxins and the biostimulator AlgaminoPlant on rhizogenesis in stem cuttings of two dogwood cultivars (Cornus alba 'Aurea' and 'Elegantissima'). Acta Sci. Pol., Hortorum Cultus 11: 93-103.

Pacholczak A., Szydło W., Petelewicz P., Szulczyk K., 2013. The effect of AlgaminPlant on rhizogenesis in stem cuttings of Physocarpus opulifolius 'Dart's Gold' and 'Red Baron'. Acta Sci. Pol., Hortorum Cultus 12(3): 105-116.

Pacholczak A., Pietkiewicz S., 2014. Gas exchange during rhizogenesis in common ninebark stem cuttings treated with biostimulators. Propag. Ornam. Plants 14(2): 90-96.

Pirlak L., 2000. Effects of different cuttings times and IBA doses on the rooting rate of hardwood cuttings of cornelian cherry (Cornus mas L.). Anadolu J. AARI 10(1): 122-134.

Poşta D.S., Hernea C., 2011. The influence of rooting biostimulators and substrate on biometric characteristics of Kerria japonica (L.) DC seedlings. JHFB 15: 88-91.

PRUSZYŃSKI S., 2008. Miejsce biostymulatorów w ochronie roślin i nawożeniu [Place biostimulators in crop protection and fertilization]. Wieś Jutra 5: 23 25.

Przybysz A., Wrochna M., SŁowiński A., Gawrońska H., 2010. Stimulatory effect of Asahi SL on selected plant species. Acta Sci. Pol., Hortorum Cultus 9: 5364.

Rathore S.S., Chaudhary D.R., Boricha G.N., Gosh A., Bhatt B.P., Zadope S.T., et al., 2009. Effect of seaweed extract on growth, yield and nutrient uptake of soybean (Glycine max) under rainfed conditions. S. Afr. J. Bot. 75: 351-355.

Rosen H., 1957. A modified ninhydrin colorimetric analysis for amino acids. Arch. Biochem. Biophys. 67: $10-15$.

RosŁon W., Osińska E., Bączek K., Węglarz Z., 2011. The influence of organic-mineral fertilizers on field and raw materials quality of chosen plants of the Lamiaceae family from organic cultivation. Acta Sci. Pol., Hortorum Cultus 10: 147-158.

Scagel C.F., Linderman R.G., 2001. Modification of root IAA concentration, tree growth, and survival by application of plant growth regulating substances to container-grown conifers. New Forest 21: 159-186.

SHevchenko Y., 2008. Effects of biostimulators on growth and physiological reactions of vegetables - tested on cucumber (Cucumis sativus L.). Ph.D. dissertation, Humboldt-Universität, Berlin, Germany, $182 \mathrm{p}$.

Sivasankari S., Venkatesalu V., Anantharaj M., Chandrasekaran M., 2006. Effect of seaweed extracts on the growth and biochemical constants of Vigna sinensis. Bioresour. Technol. 97: 1745-1751.

Snedecor G.W., Cochran W.G., 1967. Statistical Methods. The Iowa State University Press, Ames, Iowa, USA: 593.

Szabó V., Нrotkó K., 2009. Preliminary results of biostimulator treatments on Crataegus and Prunus stockplants. Bulletin UASVM Horticulture 66: 223228.

Vician M., KováčIK P., 2013. The effect of folic application of MG-Titanit fertilizer on phytomass, chlorophyll production and the harvest of winter wheat. Conf. MendelNet, 20-21 November, Brno: 162-168.

Wóscik A.R., LAUdAŃski Z., 1989. Planowanie i wnioskowanie statystyczne w doświadczalnictwie [Statistical Planning and Concluding in Experimental Works]. PWN, Warszawa, Poland: 130.

Wróbel J., Woźniak A., 2008. The effect of Atonik plant growth stimulator on chemical composition of 
common osier Salix viminalis L., grown in different substrates. Proc. Conf. „Biostimulators in modern agriculture", 7-8 February, Warsaw, Poland: 84.

Zaman M., Kurepin L., Catto W., Pharis P., 2015.

Evaluating the use of plant hormones and biostimulators in forage pastures to enhance shoot dry biomass production by perennial ryegrass (Lolium perenne L.): Biological enhancement of pasture dry biomass. J. Sci. Food Agric. 96(3): 715726.

Received February 12, 2016; accepted May 19, 2016 